ISSN: 2302-8556

E-Jurnal Akuntansi Universitas Udayana

Vol.22.2. Februari (2018): 856-883

DOI: https://doi.org/10.24843/EJA.2018.v22.i02.p02

\title{
Investment Opportunity Set (IOS) Sebagai Pemoderasi Pengaruh Profitabilitas Dan Kepemilikan Manajerial Terhadap Kebijakan Utang
}

\author{
A. A. Putri Rahayu ${ }^{1}$ \\ Gerianta Wirawan Yasa ${ }^{2}$
}

${ }^{1}$ Fakultas Ekonomi dan Bisnis Universitas Udayana (Unud), Bali, Indonesia
email: gekputri15@ yahoo.com/ Telp : 085857134998
${ }^{2}$ Fakultas Ekonomi dan Bisnis Universitas Udayana (Unud), Bali, Indonesia

\begin{abstract}
ABSTRAK
Penelitian ini bertujuan untuk mengetahui pengaruh profitabilitas dan kepemilikan manajerial terhadap kebijakan utang yang di moderasi oleh Investment Opportunity Set (IOS). Penelitian ini dilakukan pada perusahaan manufaktur yang terdaftar di Bursa Efek Indonesia (BEI) periode 2012-2014. Jumlah sampel yang diperoleh sebanyak 126 perusahaan, dengan metode penentuan sampel purposive sampling. Teknik analisis data yang digunakan adalah Moderated Regression Analysis (MRA). Berdasarkan hasil analisis ditemukan bahwa profitabilitas tidak berpengaruh negatif terhadap kebijakan utang. Kepemilikan manajerial berpengaruh negatif terhadap kebijakan utang. Investment opportunity set (IOS) tidak mampu memperkuat pengaruh negatif profitabilitas terhadap kebijakan utang. Investment opportunity set (IOS) memperlemah pengaruh negatif kepemilikan manajerial terhadap kebijakan utang.

Kata Kunci : Kebijakan utang, profitabilitas, kepemilikan manajerial, dan investment opportunity set (IOS).
\end{abstract}

\begin{abstract}
This study aims to determine the effect of profitability and managerial ownership of debt policy in moderation by Investment Opportunity Set (IOS). This research was conducted at a manufacturing company listed on Indonesia Stock Exchange (IDX) period 2012-2014. The number of sample is 126 companies, with purposive sampling method. Data analysis technique used is Moderated Regression Analysis (MRA).Based on the results of the analysis found that profitability does not negatively affect debt policy. Managerial ownership negatively affects debt policy. Investment opportunity set (IOS) is unable to reinforce the negative effect of profitability on debt policy. Investment opportunity set (IOS) weakens the negative influence of managerial ownership on debt policy.
\end{abstract}

Keywords: Debt policy, profitability, managerial ownership, and investment opportunity set (IOS). 


\section{PENDAHULUAN}

Perusahaan yang terdaftar dalam Bursa Efek Indonesia (BEI) merupakan perusahaan go public yang membutuhkan dana besar untuk dapat tumbuh dan berkembang ditengah persaingan yang semakin kompleks. Yulianto (2010) menyatakan bahwa pendanaan merupakan komponen yang sangat penting bagi setiap perusahaan karena dengan dana yang dimiliki maka perusahaan dapat mencapai tujuan utamanya yaitu menghasilkan keuntungan. Pemenuhan dana perusahaan dapat berasal dari sumber internal maupun dari sumber eksternal (Riyanto, 2001:209). Sumber dana internal berasal dari laba ditahan sedangkan sumber dana eksternal berasal dari para kreditur dalam bentuk utang dan pemilik yang disebut modal.

Menurut (Mamduh, 2004) dalam pecking order theory menyatakan bahwa perusahaan lebih cenderung menggunakan dana internal terlebih dahulu untuk mendanai kegiatan operasionalnya dibandingkan dengan penggunaan dana yang bersumber dari eksternal. Namun, ketika sumber dana internal sudah tidak mencukupi lagi maka penggunaan sumber dana eksternal dalam bentuk utang dilakukan oleh perusahaan. Perusahaan menganggap bahwa penggunaan utang dirasa lebih aman daripada menerbitkan saham baru dengan beberapa alasan. Pertama, adalah pertimbangan biaya emisi. Biaya emisi utang akan lebih murah daripada biaya emisi saham baru. Hal ini disebabkan karena penerbitan saham baru akan menurunkan harga saham lama. Kedua, manajer khawatir kalau penerbitan saham baru akan ditafsirkan sebagai kabar buruk oleh para pemodal dan membuat harga saham akan 
ISSN: 2302-8556

E-Jurnal Akuntansi Universitas Udayana

Vol.22.2. Februari (2018): 856-883

turun. Penggunaan dana dengan utang juga dapat mengurangi jumlah pajak yang harus dibayarkan kepada pemerintah.

Utang adalah semua kewajiban keuangan perusahaan kepada pihak lain yang belum terpenuhi (Munawir, 2004). Kewajiban tersebut harus dibayarkan kembali pada waktu tertentu disertai dengan sejumlah bunga yang ditetapkan sendiri oleh pihak kreditur. Semakin besar proporsi utang perusahaan maka semakin tinggi beban pokok dan bunga yang harus dibayarkan kembali serta semakin tinggi pula risiko kebangkrutan. Oleh karena itu, perusahaan harus mampu membuat suatu kebijakan utang yang tepat agar utang yang digunakan, dapat membantu perusahaan untuk tumbuh dan berkembang sehingga tidak terjadi kegagalan dalam membayar utang.

PT. Davomas Abadi Tbk. merupakan salah satu produsen kakao dan bubuk cokelat terbesar di Indonesia, yang mengalami kebangkrutan akibat lemahnya fundamental keuangan, manajemen yang tidak solid, dan tidak mampu membayar utang-utangnya sebesar 13,09 juta dolar (Kompas, 9 Pebruari 2010). Agar tidak terjadi permasalahan yang serius di masa yang akan datang maka besarnya dana eksternal dalam bentuk utang harus dikendalikan dengan kebijakan.

Kebijakan utang adalah kebijakan yang diambil oleh pihak manajemen dalam rangka memeroleh sumber pembiayaan bagi perusahaan sehingga dapat digunakan untuk membiayai aktivitas operasional perusahaan (Setiana dan Reffina, 2013). Perusahaan yang memiliki tingkat pertumbuhan yang tinggi cenderung akan memerlukan dana yang besar untuk mengembangkan usahanya. Dalam rangka hal tersebut manajemen akan mengambil keputusan untuk menggunakan dana internal 
yaitu laba ditahan untuk melakukan investasi, namun di pihak pemegang saham menginginkan agar laba ditahan dibagikan dalam bentuk dividen dengan harapan jika perusahaan membagikan dividen, nilai perusahaan akan meningkat dari sudut pandang investor, sehingga nilai sahamnya akan mengalami kenaikan. Agar memenuhi kebutuhan dana tersebut pemegang saham menyarankan kepada manajemen untuk melakukan pinjaman sehingga manajemen akan lebih berhati-hati dalam penggunaannya.

Menurut (Karsana dan Supriyadi, 2004) manajer perusahaan (agen) cenderung berperilaku oportunis demi kepentingannya sendiri, yang sering tidak sejalan dengan kepentingan pemegang saham (prinsipal). Untuk membatasi tindakan manajer yang oportunis, pemegang saham memerlukan upaya pengawasan (monitoring). Tindakan pengawasan pemegang saham ini menimbulkan biaya keagenan yang terjadi karena adanya perbedaan kepentingan antara kedua belah pihak, di mana pemegang saham menginginkan sisa dana tersebut dibagikan untuk meningkatkan kesejahteraannya, sedangkan manajer menginginkan dana digunakan untuk investasi pada proyekproyek yang menguntungkan karena pada masa mendatang akan menambah insentif bagi manajer. Dalam menyelesaikan masalah keagenan ini pemegang saham perlu mekanisme untuk meminimumkan biaya keagenan melalui kebijakan utang, karena dengan adanya kebijakan utang akan terdapat monitoring dari pihak debtholder (kreditur).

Kebijakan utang dapat diputuskan dengan mempertimbangkan besar kecilnya profitabilitas perusahaan dan kepemilikan saham manajerial. Profitabilitas 
ISSN: 2302-8556

E-Jurnal Akuntansi Universitas Udayana Vol.22.2. Februari (2018): 856-883

menentukan keputusan tentang kebijakan utang yang akan diambil dalam perusahaan. Profitabilitas adalah kemampuan suatu perusahaan untuk menghasilkan laba selama periode tertentu (Munawir, 2003:33). Sedangkan menurut (Mamduh dan Abdul Halim, 2000), profitabilitas adalah rasio yang mengukur kemampuan perusahaan menghasilkan keuntungan (profit) pada tingkat penjualan, aset, dan modal saham tertentu. Menurut (Bouzoita dan Young 1998) dan (Bourton et al.,1989), semakin tinggi profitabilitas maka semakin rendah default risk atau risiko ketidakmampuan membayar suatu perusahaan. Perusahaan dengan tingkat profitabilitas yang tinggi umumnya menggunakan utang dalam jumlah yang relatif sedikit karena dengan tingkat pengembalian investasi yang tinggi perusahaan dapat melakukan permodalan dengan laba ditahan saja (Erni Masdupi, 2008). (Myers et al., 1984) menyarankan manajer untuk menggunakan pecking order untuk keputusan pendanaan. Pecking order merupakan urutan penggunaan dana untuk investasi yaitu laba ditahan sebagai pilihan pertama, kemudian diikuti oleh utang dan ekuitas. Teori ini mengimplikasikan adanya hubungan negatif antara profitabilitas perusahaan dengan tingkat utang. Pihak insider tidak mau berbagi keuntungan dengan kreditur sehingga ada kecenderungan tingkat utang perusahaan lebih kecil. (Myers et al.,1984); (Jensen et al.,1992); (Moh'd et al.,1998); (Nurbaiti, 2007); serta (Yeniatie dan Destriana 2010) menemukan adanya pengaruh negatif antara profitabilitas dengan kebijakan utang. Hasil tersebut tidak konsisten dengan penelitian yang dilakukan oleh (Mas'ud, 2008); (Margareta dan Ramadhan 2009); dan (Hardiningsih, 2012) yang menghasilkan profitabiltas berpengaruh positif terhadap kebijakan utang. 
Kepemilikan saham manajerial adalah situasi di mana manajer memiliki saham perusahaan atau dengan kata lain manajer sekaligus sebagai pemegang saham (Cristiawan dan Josua, 2007). (Magginson, 1997) menyatakan bahwa kepemilikan manajerial dalam hubungannya dengan kebijakan utang mempunyai peranan penting dalam mengendalikan keuangan perusahaan agar sesuai dengan keinginan para pemegang saham. Utang yang rendah diharapkan mengurangi risiko kebangkrutan dan financial distress. Semakin besar proporsi kepemilikan saham yang dimiliki manajer maka akan menurunkan tingkat utang sehingga meminimalisir tingkat risiko yang dialami perusahaan (Pawestri, 2010).

Pengaruh antara kepemilikan manajerial terhadap kebijakan utang dari penelitianpenelitian sebelumnya memberikan hasil yang tidak konsisten. Penelitian dari (Wahidahwati, 2002) menguji kepemilikan manajerial dan kepemilikan institusional pada kebijakan utang. Hasil penelitiannya terdapat hubungan negatif antara kepemilikan manajerial dengan kebijakan utang, yang artinya peningkatan kepemilikan manajerial akan mempengaruhi pengambilan keputusan perusahaan mengenai utang sehingga penggunaan utang menjadi rendah. Hasil ini konsisten dengan penelitian yang dilakukan oleh (Listyani, 2003), (Zulhawati, 2004), (Masdupi, 2005), (Moh'd et al., 1998) dalam (Wahidahwati 2002). Tetapi hasil penelitian (Agrawal dan Mendelker, 1987) dalam (Wahidahwati, 2002), menyatakan bahwa terdapat hubungan positif antara kebijakan utang dan kepemilikan manajerial. (Agrawal dan Mendelker, 1987) menguji hubungan antara saham dan opsi yang 
ISSN: 2302-8556

E-Jurnal Akuntansi Universitas Udayana Vol.22.2. Februari (2018): 856-883

dipegang oleh manajer serta karakteristik dari keputusan investasi yang diambil oleh perusahaan terutama perubahan dalam return on asset.

Pada penelitian-penelitian sebelumnya terdapat hasil yang tidak konsisten akibat perbedaan variabel. Penelitian ini menggunakan variabel moderasi yang dapat memperkuat atau memperlemah pengaruh setiap variabel yang diteliti. Dalam penelitian ini investment opportunity set (IOS) digunakan sebagai variabel moderasi. Investment opportunity set (IOS) merupakan set kesempatan berinvestasi yang juga dapat digunakan sebagai dasar untuk menentukan klasifikasi pertumbuhan perusahaan dimasa depan (Damayanti, 2006). Investment opportunity set (IOS) merupakan karakteristik penting perusahaan dan sangat mempengaruhi cara pandang manajer, pemilik, investor dan kreditur terhadap perusahaan (Kallapur dan Trombley, 2001 dalam Saputro, 2003). Tersedianya alternatif investasi di masa mendatang bagi perusahaan ini disebut dengan Set Kesempatan Investasi (Setiawan dan Hartono, 2003). Investment opportunity set (IOS) merupakan bentuk investasi yang dilakukan perusahaan untuk menghasilkan nilai bagi perusahaan di masa yang akan datang. Semakin tinggi investment opportunity set (IOS) maka perusahaan akan memiliki nilai di masa yang akan datang dan akan dinilai tinggi oleh investor, demikian juga sebaliknya.

Menurut (Tarjo dan Jogiyanto, 2003), jika kepemilikan manajerial meningkat akan memengaruhi pengambilan keputusan pada utang perusahaan terutama apabila diketahui set kesempatan investasi perusahaan tinggi maka kebijakan utang akan rendah. Penelitian ini sejalan dengan pecking order theory. Disaat manajer memiliki 
sejumlah saham dalam perusahaan diharapkan mampu untuk menurunkan risiko kebangkrutan dengan menurunkan tingkat penggunaan utang perusahaan. Begitu juga saat perusahaan memiliki set kesempatan investasi yang besar diharapkan mampu untuk mempertahankan bahkan lebih menurunkan penggunaan utang dalam perusahaan.

Penelitian mengenai kebijakan utang dilakukan pada sektor manufaktur yang terdaftar di Bursa Efek Indonesia (BEI) pada tahun 2012-2014. Alasan peneliti memilih perusahaan manufaktur sebagai objek penelitian dikarenakan perusahaan manufaktur merupakan perusahaan yang menjual produknya yang dimulai dengan proses produksi yang tidak terputus mulai dari pembelian bahan baku, proses pengolahan bahan hingga menjadi barang jadi. Dimana hal ini dilakukan sendiri oleh perusahaan tersebut sehingga membutuhkan sumber dana yang akan digunakan pada aset tetap perusahaan. Perusahaan manufaktur lebih membutuhkan sumber dana jangka panjang untuk membiayai operasi perusahaan mereka salah satunya dengan investasi, sehingga dapat mempengaruhi kebijakan utang perusahaan (Devi dan Erawati, 2014). Hal ini menjadikan perusahaan manufaktur selalu mendapat perhatian dan sorotan dari pelaku pasar. Perusahaan manufaktur merupakan sektor terbesar di BEI sehingga kinerja perusahaan manufaktur akan berpengaruh signifikan terhadap kinerja pasar modal. Adanya pergeseran preferensi penanaman modal baik dari domestik maupun asing dari sektor pertambangan menuju sektor manufaktur mengindikasikan bahwa sektor ini memiliki prospek yang baik dan alasan lainnya adalah minimnya regulasi dari pemerintah atas kebijakan ekonomi pada perusahaan 
ISSN: 2302-8556

E-Jurnal Akuntansi Universitas Udayana Vol.22.2. Februari (2018): 856-883

manufaktur. Kepercayaan investor terhadap perusahaan manufaktur yang memiliki keputusan investasi tinggi pada saat ini, menyebabkan naiknya permintaan terhadap saham perusahaan manufaktur di Indonesia (Suartawan, 2015). Berdasarkan latar belakang dan penelitian sebelumnya, maka peneliti tertarik untuk melakukan penelitian tentang Investment Oportunity Set (IOS) sebagai pemoderasi pengaruh Profitabilitas dan Kepemilikan Manajerial terhadap Kebijakan Utang.

Profitabilitas merefleksikan earnings untuk pendanaan investasi. Menggunakan pecking order disarankan kepada manajer untuk keputusan pendanaan (Myers, 1984). Pecking order merupakan urutan penggunaan dana untuk investasi yang pertama adalah laba ditahan, kemudian utang dan ekuitas menjadi urutan selanjutnya. Jika ini benar, terdapat hubungan negatif antara profitabilitas perusahaan dengan tingkat utang adalah implikasinya. Pihak insider tidak mau berbagi keuntungan dengan kreditur sehingga ada kecenderungan tingkat utang perusahaan lebih kecil. (Myers et al., 1984); (Jensen et al., 1992); (Moh'd et al., 1998); (Nurbaiti, 2007); serta (Yeniatie dan Destriana, 2010) menemukan terdapat pengaruh negatif antara profitabilitas dengan kebijakan utang. Penelitian yang dilakukan oleh (Ismiyanti dan Hanafi, 2003) sejalan dengan hal tersebut. Untuk membiayai operasional, perusahaan menggunakan utang pada tingkat profitabilitas rendah. Sebaliknya perusahaan mengurangi penggunaan utang pada tingkat profitabilitas tinggi. Hal ini disebabkan karena sebagian besar keuntungan perusahaan dialokasikan pada laba ditahan sehingga mengandalkan sumber internal dan menggunakan utang tinggi sebagai mekanisme pentransfer kekayaan antara kreditur kepada prinsipal. Arah hubungan 
profitabilitas perusahaan dengan kebijakan utang sesuai dengan yang dikemukakan oleh (Myers et al., 1984) dan (Jensen et al., 1992). Berdasarkan uraian yang telah dijelaskan dapat dirumuskan hipotesis sebagai berikut:

$\mathrm{H}_{1}$ : Profitabilitas memiliki pengaruh negatif terhadap kebijakan utang

Kepemilikan manajerial adalah situasi dimana manajer memiliki saham perusahaan atau dengan kata lain manajer sekaligus sebagai pemegang saham (Christiawan dan Josua, 2007). Kepemilikan manajerial menunjukkan adanya peran ganda seorang manajer, yakni manajer bertindak juga sebagai pemegang saham. (Teori Jensen dan Meckling, 1976) menyatakan bahwa proporsi kepemilikan saham yang dikontrol oleh manajer dapat mempengaruhi kebijakan perusahaan. (Wahidahwati, 2002) menguji kepemilikan manajerial dan kepemilikan institusional pada kebijakan utang. Hasil penelitiannya terdapat hubungan negatif antara kepemilikan manajerial dengan kebijakan utang, yang artinya peningkatan kepemilikan manajerial akan mempengaruhi pengambilan keputusan perusahaan mengenai utang sehingga penggunaan utang menjadi rendah. Hasil ini konsisten dengan penelitian yang dilakukan oleh (Listyani, 2003), (Zulhawati, 2004), (Masdupi 2005), (Moh'd et al.,1998) dalam (Wahidahwati, 2002). Berdasarkan uraian yang telah dijelaskan dapat dirumuskan hipotesis sebagai berikut:

$\mathrm{H}_{2}$ : Kepemilikan manajerial berpengaruh negatif pada kebijakan utang.

Pecking order theory menyatakan bahwa perusahaan lebih cenderung menggunakan dana internal terlebih dahulu untuk mendanai kegiatan operasionalnya dibandingkan dengan penggunaan dana yang bersumber dari eksternal (Mamduh, 
ISSN: 2302-8556

E-Jurnal Akuntansi Universitas Udayana

Vol.22.2. Februari (2018): 856-883

2004). Pada saat perusahaan memiliki profitabilitas yang tinggi maka akan berpengaruh pada keputusan terkait utang perusahaan, terutama jika diketahui investment opportunity set (IOS) tinggi maka kebijakan utang akan rendah.

Investment opportunity set (IOS) yang tinggi akan memperkuat pengaruh negatif profitabilitas terhadap kebijakan utang. Pada saat adanya peluang investasi akan membuat profitabilitas yang tinggi sehingga dapat mengurangi kebijakan utang dalam perusahaan dan perusahaan dapat terhindar dari risiko utang yang tinggi.

Berdasarkan uraian di atas dapat ditarik hipotesis penelitian yaitu sebagai berikut:

$\mathrm{H}_{3}$ : Investment opportunity set (IOS) memperkuat pengaruh negatif Profitabilitas pada kebijakan utang.

Kepemilikan manajerial menunjukkan adanya peran ganda seorang manajer, yakni manajer bertindak juga sebagai pemegang saham. Sebagai seorang manajer sekaligus pemegang saham, tentunya manajer tidak ingin perusahaan mengalami kesulitan keuangan atau bahkan kebangkrutan. (Tarjo dan Jogiyanto, 2003) mengatakan bahwa jika kepemilikan manajerial meningkat akan berpengaruh pada keputusan terkait utang perusahaan, terutama jika diketahui investment opportunity set (IOS) tinggi maka kebijakan utang akan rendah.

Adanya investment opportunity set (IOS) yang tinggi akan memperkuat pengaruh kepemilikan manajerial pada kebijakan utang. Pihak manajerial akan lebih memilih untuk mengambil kesempatan untuk berinvestasi dan mendapatkan keuntungan daripada mengambil risiko yang tinggi dengan menggunakan utang.

Berdasarkan penjelasan diatas, dapat dirumuskan hipotesis sebagai berikut: 
$\mathrm{H}_{4}$ : Investment opportunity set (IOS) memperkuat pengaruh negatif kepemilikan manajerial pada kebijakan utang.

\section{METODE PENELITIAN}

Penelitian ini menggunakan pendekatan kuantitatif dengan bentuk asosiatif yaitu untuk mengetahui hubungan antara dua variabel independen atau lebih dengan variabel dependen. Lokasi atau ruang lingkup dalam penelitian ini adalah perusahaan manufaktur yang terdaftar di Bursa Efek Indonesia (BEI) dengan menggunakan laporan keuangan auditan yang dapat diakses melalui www.idx.co.id. Objek dalam penelitian ini adalah kebijakan utang pada perusahaan manufaktur yang terdaftar di Bursa Efek Indonesia tahun 2012-2014. Tahun penelitian dimulai dari tahun 20122014 karena pada tahun 2012 Indonesian GAAP (PSAK) mengadopsi International Financial Reporting Standard (IFRS) dalam laporan keuangan.

Penelitian ini menggunakan satu variabel dependen, dua variabel independen dan satu variabel pemoderasi. Variabel dependen dalam penelitian ini adalah kebijakan utang. Variabel independen dalam penelitian ini profitabilitas dan kepemilikan manajerial. Variabel moderasi dalam penelitian ini adalah investment opportunity set (IOS). Kebijakan utang adalah segala jenis utang yang dibuat atau diciptakan oleh perusahaan baik utang lancar maupun utang jangka panjang (Nasser dan Firlano, 2006). Profitabilitas merupakan kemampuan perusahaan untuk menghasilkan laba pada masa yang akan datang (Jansen, et al., 1992).

Kepemilikan manajerial (KM) adalah kepemilikan saham oleh pihak manajemen. Kepemilikan manajerial diukur sesuai dengan proporsi kepemilikan 
ISSN: 2302-8556

E-Jurnal Akuntansi Universitas Udayana Vol.22.2. Februari (2018): 856-883

saham yang dimiliki oleh pihak manajemen (Wahidahwati, 2002). Investment opportunity set (IOS) yang merupakan variabel moderasi dalam penelitian ini dapat diukur dengan proksi berdasarkan harga/Market to Book Value of Equity (MBVE) yang dimiliki oleh perusahaan pada akhir tahun.

Jenis data dalam penelitian ini menurut sifatnya menggunakan data kuantitatif yaitu data yang berupa angka yang diperoleh dari laporan keuangan auditan perusahaan. Penelitian ini menggunakan sumber data sekunder yaitu data yang berasal dari pihak lain. Data sekunder berupa laporan keuangan auditan yang dipublish di BEI tahun 2012-2014. Laporan keuangan tersebut diperoleh dari website www.idx.co.id. Populasi dalam penelitian ini adalah seluruh perusahaan nonkeuangan yang terdaftar di BEI. Perusahaan manufaktur dipilih karena pada umumnya perusahaan manufaktur merupakan perusahaan yang mendominasi perusahaanperusahaan yang terdaftar di Bursa Efek Indonesia (BEI). Sekitar 150 perusahaan dalam industri manufaktur tersebut dikelompokkan menjadi beberapa sub kategori industri. Banyaknya perusahaan dalam industri, serta kondisi perekonomian saat ini telah menciptakan suatu persaingan yang ketat antar perusahaan manufaktur.

Penelitian ini mengacu pada pengumpulan dokumen di mana data yang diperoleh tidak didapatkan secara langsung. Dokumen tersebut berupa laporan keuangan auditan dari perusahaan yang terdaftar di BEI tahun 2012-2014. Sebelum dilakukan analisis regresi linear berganda, terlebih dahulu harus melalui uji asumsi klasik, untuk memastikan bahwa model yang diperoleh benar- benar memenuhi asumsi dasar dalam analisis regresi. Uji asumsi klasik yang dilakukan, terdiri dari uji 
normalitas, uji autokorelasi, uji multikolinearitas, dan uji heteroskedastisitas.

teknik analisis data yang digunakan adalah analisis regresi linear berganda atau Moderated Regression Analysis (MRA). MRA merupakan aplikasi khusus regresi linear berganda yang didalam persamaan regresinya mengandung unsur interaksi (perkalian dua atau lebih variabel independen). Regresi linear berganda digunakan untuk menganalisis apakah hipotesis penelitian terbukti signifikan atau tidak. Analisis regresi linear berganda akan dilakukan dengan menggunakan Statistical Product and Service Solution (SPSS). Adapun rumus persamaan dalam penelitian ini adalah sebagai berikut:

$\mathrm{Y}=\alpha+\beta_{1} \mathrm{PROF}+\beta_{2} \mathrm{KM}+\beta_{3} \mathrm{IOS}+\beta_{4}$ PROF. IOS $+\beta_{5}$ KM.IOS $+\varepsilon$

Keterangan:

\begin{tabular}{|c|c|}
\hline $\mathrm{Y}$ & $=$ Kebijakan Utang \\
\hline$\alpha$ & $=$ Konstanta \\
\hline$\beta_{1}, \beta_{2}, \beta_{3}, \beta_{4}, \beta_{5}$ & $=$ Koefisien regresi \\
\hline PROF & $=$ Profitabilitas \\
\hline $\mathrm{KM}$ & $=$ Kepemilikan Manajerial \\
\hline IOS & $=$ Investment Opportunity Set \\
\hline PROF.IOS & $=$ Interaksi profitabilitas dengan investment opportunity set \\
\hline KM.IOS & $\begin{array}{l}=\text { Interaksi kepemilikan manajerial dengan investment } \\
\text { opportunity set }\end{array}$ \\
\hline & $=$ error \\
\hline
\end{tabular}

Dari hasil analisis regresi linier berganda kemudian dilihat nilai koefisien determinasi (R2) serta nilai Uji statistik F yang dihasilkan. Koefisien Determinasi yaitu pengujian yang dilakukan untuk mengetahui persentase pengaruh variabel independen pada perubahan variabel dependen. Uji statistik F pada dasarnya menunjukkan apakah semua variabel bebas yang dimasukkan dalam model mempunyai pengaruh secara bersama-sama pada variabel dependen (Ghozali, 2009). 
ISSN: 2302-8556

E-Jurnal Akuntansi Universitas Udayana

Vol.22.2. Februari (2018): 856-883

Apabila hasil uji $\mathrm{F}$ menunjukkan signifikan $\mathrm{F}$ atau $\mathrm{p}$ value $\leq 0,05$ maka hubungan antar variabel bebas adalah signifikan memengaruhi kebijakan utang.

\section{HASIL DAN PEMBAHASAN}

Perusahaan dipilih dengan menggunakan teknik purposive sampling sesuai dengan kriteria yang telah ditetapkan. Proses penyeleksian sampel dalam penelitian ini adalah sebagai berikut dalam Tabel 1:

\section{Tabel 1.}

Seleksi Jumlah Sampel Penelitian

\begin{tabular}{clc}
\hline No & \multicolumn{1}{c}{ Keterangan } & Jumlah \\
\hline 1 & $\begin{array}{l}\text { Perusahaan manufaktur yang terdaftar di BEI selama tahun } \\
\text { 2012 s/d 2014 }\end{array}$ & 128 \\
2 & $\begin{array}{l}\text { Perusahaan manufaktur yang tidak konsisten } \\
\text { mempublikasikan laporan keuangan auditan dan annual } \\
\text { report selama periode pengamatan dari }\end{array}$ & \\
& $\begin{array}{l}\text { tahun 2012-2014 } \\
3\end{array}$ & $\begin{array}{l}\text { Perusahaan yang tidak mempublikasikan laporan keuangan } \\
\text { dengan mata uang rupiah }\end{array}$ \\
$\quad \begin{array}{l}\text { Sampel } \\
\text { Jumlah data outlier }\end{array}$ & 79 \\
& $\begin{array}{l}\text { Jumlah sampel yang digunakan setelah data } \\
\text { Outlier }\end{array}$ & $(37)$ \\
\hline & Jumlah pengamatan (42 perusahaan x 3 tahun) & 42 \\
\hline
\end{tabular}

Sumber : Data sekunder yang diolah, 2016

Berdasarkan Tabel 1 diperoleh data pengamatan sebanyak 126 perusahaan manufaktur. Hasil pengolahan data mengidentifikasikan adanya data outlier sebanyak 37 sampel, sehingga jumlah sampel dalam penelitian ini menjadi 42 perusahaan manufaktur. Outlier adalah kasus atau data yang memiliki karakteristik unik yang terlihat sangat berbeda jauh dari observasi-observasi lainnya dan muncul dalam bentuk nilai ekstrim baik untuk variabel tunggal atau variabel kombinasi 
(Ghozali, 2009:40). Menurut (Hair, 1998) dalam (Ghozali, 2009:40) menyatakan bahwa untuk kasus sampel kecil (kurang dari 80), maka standar skor dengan nilai 2,5 dapat dinyatakan outlier. Adanya data outlier menyebabkan jumlah pengamatan berubah dari $237(79 \times 3$ tahun $)$ pengamatan menjadi $126(42 \times 3$ tahun $)$ pengamatan.

Analisis statistik deskriptif dilakukan untuk memberikan gambaran atau deskripsi mengenai variabel penelitian melalui nilai rata-rata (mean), nilai minimum, nilai maksimum, dan deviasi standar. Analisis dari statistik deskriptif selengkapnya dapat dilihat pada Tabel 2.

Tabel 2. Statistik Deskriptif Data Uji

\begin{tabular}{llllll}
\hline & $\mathbf{N}$ & Minimum & Maksimum & Rata-rata & $\begin{array}{c}\text { Standar } \\
\text { Deviasi }\end{array}$ \\
\hline DER & 126 & 0,04 & 2,49 & 0,50 & 0,38 \\
PROF & 126 & $-3,07$ & 74,84 & 9,48 & 9,62 \\
KM & 126 & 0,00 & 0,78 & 0,09 & 0,19 \\
IOS & 126 & 6,54 & 16,01 & 13,85 & 1,48 \\
PROF*IOS & 126 & $-40,98$ & 1006,89 & 134,76 & 138,33 \\
KM*IOS & 126 & 0,00 & 11,96 & 1,35 & 2,81 \\
\hline \multicolumn{5}{l}{ Sumber $:$ data diolah, 2016}
\end{tabular}

Variabel kebijakan utang yang diproksikan dengan debt to equity ratio (DER) memiliki nilai rata-rata sebesar 0,50 . Nilai rata-rata tersebut mendekati nilai minimum 0,04. Hasil ini menunjukkan bahwa secara umum nilai rata-rata perusahaan manufaktur yang menjadi sampel dalam penelitian ini memiliki kebijakan utang yang rendah. Hal ini berarti modal perusahaan cenderung lebih sedikit dibiayai oleh utang.

Variabel profitabilitas yang diproksikan dengan return on asset (ROA) memiliki nilai rata-rata sebesar 9,48. Nilai rata-rata tersebut mendekatai nilai minimum -3,07. 
ISSN: 2302-8556

E-Jurnal Akuntansi Universitas Udayana Vol.22.2. Februari (2018): 856-883

Hasil ini menunjukkan bahwa secara umum nilai rata-rata perusahaan manufaktur yang menjadi sampel dalam penelitian ini memiliki profitabilitas yang masih rendah.

Kepemilikan manajerial (KM) dalam penelitian ini diukur menggunakan persentase kepemilikan saham oleh manajemen. Berdasarkan Tabel 4.2 variabel kepemilikan manajerial memiliki nilai rata-rata sebesar 0,09. Hasil ini menunjukkan bahwa secara umum nilai rata-rata perusahaan manufaktur yang menjadi sampel dalam penelitian ini memiliki kepemilikan manajerial yang masih rendah.

Variabel investment opportunity set (IOS) yang diproksikan dengan rasio market to book value of equity memiliki nilai rata-rata sebesar 13,85 yang berarti bahwa secara umum rata-rata perusahaan manufaktur yang menjadi sampel dalam penelitian ini memiliki investment opportunity set atau set kesempatan investasi sebesar dari nilai bukunya.

Variabel interaksi profitabilitas dengan investment opportunity set (PROF*IOS) memiliki nilai rata-rata sebesar 134,76 . Nilai rata-rata tersebut mendekatai nilai minimum -40,98. Variabel interaksi kepemilikan manajerial dengan investment opportunity set $\left(\mathrm{KM}^{*} \mathrm{IOS}\right)$ memiliki nilai rata-rata sebesar 1,35 . Nilai rata-rata tersebut mendekatai nilai minimum 0,00 .

Pengujian ini dilakukan untuk menguji apakah dalam sebuah model regresi (variabel dependen atau variabel independen ataupun keduanya) memiliki distribusi normal atau tidak. Nilai signifikansi Kolmogorov-Smirnov di atas 0,05 (asymp.sig = 0,074). Hasil pengujian tersebut menunjukkan bahwa nilai Asymp. Sig (2-tailed) 
lebih besar dari level of significant $5 \%(0,05)$ sehingga data yang diuji menyebar normal atau berdistribusi normal. Pengujian Multikolinearitas bertujuan untuk menguji apakah pada model regresi ditemukan adanya korelasi antar variabel bebas, karena model regresi yang baik seharusnya tidak terjadi korelasi diantara variabel bebas. Semua variabel independen memiliki nilai tolerance lebih besar dari 10 persen $(0,1)$ dan nilai VIF kurang dari 10 , sehingga model dikatakan tidak mengandung gejala multikolinieritas.

Uji heteroskedastisitas bertujuan untuk menguji apakah model regresi terjadi ketidaksamaan variance dari residual satu pengamatan ke pengamatan yang lain. nilai sig. pada masing-masing variabel berada di atas 0,05. Dengan demikian, model yang dibuat tidak mengandung gejala heteroskedastisitas, sehingga layak digunakan untuk memprediksi. Untuk melacak adanya korelasi auto atau pengaruh data dari pengamatan sebelumnya dalam model regresi, maka dilakukan uji autokorelasi. Dengan level of significance sebesar 5 persen, $n=126$, dan jumlah variabel bebas (k') sebanyak 2, maka diperoleh nilai $\mathrm{d}_{\mathrm{L}}=1,68$ dan $\mathrm{d}_{\mathrm{U}}=1,74$. Oleh karena nilai DurbinWatson sebesar 1,909 lebih besar dari batas atas $\left(\mathrm{d}_{\mathrm{U}}\right)$ yakni 1,74 dan kurang dari 2,26 (4- $\left.\mathrm{d}_{\mathrm{U}}\right)$, maka dapat disimpulkan bahwa d statistik berada pada daerah tidak ada autokorelasi atau model regresi yang dibuat tidak mengandung gejala autokorelasi, sehingga layak digunakan untuk memprediksi.

Moderated Regression Analysis (MRA) merupakan aplikasi khusus regresi linear untuk menentukan hubungan antara dua variabel yang dipengaruhi oleh variabel 
ISSN: 2302-8556

E-Jurnal Akuntansi Universitas Udayana Vol.22.2. Februari (2018): 856-883

ketiga (Ghozali, 2011:30). Hasil perhitungan MRA pada penelitian ini ditunjukkan pada Tabel 3.

Tabel 3.

Hasil Uji Moderated Regression Analysis

\begin{tabular}{|c|c|c|c|c|c|c|}
\hline \multirow{2}{*}{\multicolumn{2}{|c|}{ Model }} & \multicolumn{2}{|c|}{$\begin{array}{l}\text { Unstandardized } \\
\text { Coefficients }\end{array}$} & \multirow{2}{*}{$\begin{array}{c}\begin{array}{c}\text { Standardized } \\
\text { Coefficients }\end{array} \\
\text { Beta }\end{array}$} & \multirow[t]{2}{*}{$\mathbf{T}$} & \multirow[t]{2}{*}{ Sig. } \\
\hline & & B & Std. Error & & & \\
\hline \multirow[t]{6}{*}{1} & (Constant) & 0,028 & 0,598 & & 0,046 & 0,963 \\
\hline & PROF & 0,011 & 0,035 & 0,290 & 0,328 & 0,743 \\
\hline & $\mathrm{KM}$ & $-4,782$ & 2,179 & $-2,477$ & $-2,195$ & 0,030 \\
\hline & IOS & 0,039 & 0,044 & 0,151 & 0,870 & 0,386 \\
\hline & PROF_IOS & $-0,001$ & 0,003 & $-0,526$ & $-0,567$ & 0,572 \\
\hline & KM_IOS & 0,363 & 0,153 & 2,692 & 2,378 & 0,019 \\
\hline \multicolumn{2}{|c|}{ Adjusted R Square } & 0,146 & & & & \\
\hline \multicolumn{2}{|c|}{ F Statistik } & 5,275 & & & & \\
\hline \multicolumn{2}{|c|}{ Signifikansi } & 0,000 & & & & \\
\hline
\end{tabular}

Berdasarkan Tabel 3 dapat dibuat persamaan regresi sebagai berikut:

$\mathrm{Y}=0,028+0,011 \mathrm{PROF}-4,782 \mathrm{KM}-0,001 \mathrm{PROF} \_I O S+0,363 \mathrm{KM} \_I O S+\mathrm{e}$

Keterangan:

Y $\quad=$ kebijakan utang

PROF = profitabilitas

$\mathrm{KM} \quad=$ kepemilikian manajerial

IOS = investment oppourtunity set

PROF_IOS = Interaksi antara profitabilitas dan investment oppourtunity set

KM_IOS = Interaksi antara kepemilikan manajerial dan investment oppourtunity set e $=$ Error

Nilai koefisien $\beta_{1}=0,011$ menunjukkan apabila nilai profitabilitas (PROF) meningkat 1 satuan, maka nilai kebijakan utang (Y) akan mengalami kenaikan sebesar 0,011 dengan asumsi variabel independen lainnya konstan. Nilai koefisien $\beta_{2}$ 
$=-4,782$ menunjukkan apabila nilai kepemilikan manajerial $(\mathrm{KM})$ meningkat 1 satuan, maka nilai dari kebijakan utang (Y) akan mengalami penurunan sebesar 4,782 dengan asumsi variabel independen lainnya konstan. Nilai koefisien $\beta_{3}=0,039$ menunjukkan apabila nilai investment oppourtunity set (IOS) meningkat 1 satuan, maka nilai dari kebijakan utang (Y) akan mengalami kenaikan sebesar 0,039 dengan asumsi variabel independen lainnya konstan. Nilai koefisien $\beta_{4}=-0,001$ menunjukkan apabila nilai interaksi antara profitabilitas (PROF) dan investment oppourtunity set (IOS) meningkat 1 satuan, maka nilai dari kebijakan utang (Y) akan mengalami penurunan sebesar -0,001 dengan asumsi variabel independen lainnya konstan. Nilai koefisien $\beta_{5}=0,363$ menunjukkan apabila nilai interaksi antara kepemilikan manajerial (KM) dan investment oppourtunity set (IOS) meningkat 1 satuan, maka nilai dari kebijakan utang $(\mathrm{Y})$ akan mengalami peningkatan sebesar 0,363 dengan asumsi variabel independen lainnya konstan.

Nilai Adjusted $R$ Square sebesar 0,146 yang berarti bahwa 14,6 persen variasi kebijakan utang dipengaruhi oleh model yang dibentuk yaitu profitabilitas, kepemilikan manajerial, interaksi antara profitabilitas dan investment oppourtunity set dan interaksi antara kebijakaan manajerial dan investment oppourtunity set, sementara sisanya sebesar 85,4 persen dipengaruhi oleh variabel lain di luar model penelitian. nilai $\mathrm{F}$ sebesar $0,000<0,050$ yang berarti bahwa model ini berpengaruh secara simultan (serempak) pada variabel dependen dengan tingkat signifikansi 5 persen.

Hasil pengujian hipotesis pertama diperoleh bahwa variabel profitabilitas tidak berpengaruh terhadap kebijakan utang. Hasil penelitian ini terbukti menolak 
ISSN: 2302-8556

E-Jurnal Akuntansi Universitas Udayana Vol.22.2. Februari (2018): 856-883

hipotesis pertama $\left(\mathrm{H}_{1}\right)$ yang menyatakan bahwa profitabilitas berpengaruh negatif pada kebijakan utang perusahaan. Semakin tinggi atau rendah profitabilitas maka tidak akan ada pengaruhnya terhadap kebijakan utang yang diberikan.

Profitabilitas merefleksikan earnings untuk pendanaan investasi. (Myers, 1984) untuk keputusan pendanaan, manajer disarankan untuk menggunakan pecking order. Hasil penelitian ini sejalan dengan penelitian (Masdupi, 2005) yang menemukan hasil yang tidak signifikan secara statistik antara profitabilitas terhadap kebijakan utang. Hal ini berarti profitabilitas belum dipakai sebagai dasar pertimbangan dalam kebijakan utang perusahaan di Indonesia. Hasil tersebut tidak konsisten dengan hasil penelitian (Ismiyanti dan Hanafi, 2003). Pada tingkat profitabilitas rendah, perusahaan menggunakan utang untuk membiayai operasional. Sebaliknya pada tingkat profitabilitas tinggi perusahaan mengurangi penggunaan utang. Hal ini disebabkan perusahaan mengalokasikan sebagian besar keuntungan pada laba ditahan sehingga mengandalkan sumber internal dan menggunakan utang tinggi sebagai mekanisme pentransfer kekayaan antara kreditur kepada prinsipal.

Hasil pengujian hipotesis kedua diperoleh bahwa kebijakan manajerial berpengaruh negatif terhadap kebijakan utang. Hal ini berarti bahwa besar kecilnya nilai kepemilikan manajerial mampu mempengaruhi kebijakan utang dengan demikian hipotesis kedua $\left(\mathrm{H}_{2}\right)$ diterima. Nilai koefisien yang negatif menunjukkan bahwa kepemilikan manajerial berpengaruh negatif terhadap kebijakan utang. 
Kepemilikan manajerial adalah situasi dimana manajer memiliki saham perusahaan atau dengan kata lain manajer sekaligus sebagai pemegang saham (Christiawan dan Josua, 2007). Kepemilikan manajerial menunjukkan adanya peran ganda seorang manajer, yakni manajer bertindak juga sebagai pemegang saham. Hasil penelitian ini sesuai dengan Teori (Jensen dan Meckling, 1976) menyatakan bahwa proporsi kepemilikan saham yang dikontrol oleh manajer dapat mempengaruhi kebijakan perusahaan.

Hasil pengujian hipotesis ketiga diperoleh bahwa Investment opportunity set (IOS) tidak mampu memperkuat pengaruh negatif profitabilitas terhadap kebijakan utang. Hal ini menunjukan bahwa hipotesis ketiga ditolak. Hasil penelitian ini menunjukkan bahwa besar kecilnya nilai Investment opportunity set (IOS) tidak mempengaruhi pengaruh profitabilitas terhadap kebijakan utang. Penelitian ini mengindikasikan walaupun Investment opportunity set (IOS) perusahaan tinggi, hal tersebut tidak mampu memperkuat hubungan negatif profitabilitas terhadap kebijakan utang.

Hasil pengujian hipotesis keempat diperoleh bahwa Investment opportunity set (IOS) memperlemah pengaruh negatif kepemilikan manajerial terhadap kebijakan utang. Besar kecilnya nilai Investment opportunity set (IOS) mampu mempengaruhi pengaruh kepemilikan manajerial terhadap kebijakan utang. Penelitian ini mengindikasikan bahwa manajer tidak ingin hanya bergantung dari laba operasional perusahaan saja, melainkan cenderung ingin menginvestasikan dana yang dimiliki untuk meningkatkan laba bersih perusahaan. Hal inilah yang menyebabkan manajer 
membuat kebijakan utang untuk setiap kesempatan investasi yang ada.

Perusahaan yang memiliki kepemilikan manajerial yang memadai cenderung untuk tidak menggunakan utang yang tinggi pada saat perusahaan mempunyai kesempatan yang tinggi untuk berinvestasi. Perusahaan lebih memilih untuk memanfaatkan kesempatan yang ada dan manajer tidak ingin menyiakan kesempatan untuk mendapatkan keuntungan yang besar dalam berinvestasi. Dengan adanya Investment opportunity set (IOS) hubungan kepemilikan manajerial terhadap kebijakan utang menjadi lemah. Pada saat perusahaan memiliki Investment opportunity set (IOS) yang tinggi maka kebijakan utang perusahaan akan lebih rendah dikarenakan kepemilikan manajerial perusahaan lebih mementingkan untuk berinvestasi.

\section{SIMPULAN}

Berdasarkan hasil pembahasan sebelumnya, maka dapat disimpulkan sebagai berikut hipotesis pertama ditolak. Hasil penelitian menunjukkan bahwa profitabilitas tidak berpengaruh negatif terhadap kebijakan utang. Hipotesis kedua diterima. Hasil penelitian menunjukkan bahwa kepemilikan manajerial berpengaruh negatif terhadap kebijakan utang. Hipotesis ketiga ditolak. Hasil penelitian menunjukkan bahwa investment oppourtunity set tidak mampu memperkuat pengaruh negatif profitabilitas terhadap kebijakan utang. Hipotesis keempat ditolak. Hasil penelitian menunjukkan bahwa investment oppourtunity set tidak mampu memperkuat pengaruh negatif kepemilikan manajerial terhadap kebijakan utang. 
Berdasarkan simpulan diatas, saran-saran yang dapat disampaikan terkait dengan penelitian ini adalah bagi investor yang ingin melakukan investasi pada suatu perusahaan dapat mempertimbangkan besarnya kesempatan berinvestasi yang dimiliki perusahaan. Jika perusahaan tersebut memiliki kesempatan berinvestasi tinggi berarti perusahaan tersebut memiliki kesempatan untuk bertumbuh sehingga akan memberikan keuntungan bagi investor di masa yang akan datang. Berdasarkan hasil penelitian ini kepemilikan manajerial berpengaruh terhadap kebijakan utang. Sedangkan saran bagi penelitian selanjutnya dapat menambahkan variabel lain yang diduga berpengaruh pada kebijakan utang.

\section{REFERENSI}

Abin Syamsuddin Makmun. 2003. Psikologi Pendidikan. PT Rosda Karya Remaja, Bandung.

Agrawal, A. dan G.N. Mandelker. 1987. .Managerial Incentives and Corporate Investment and Financing Decisions.. Journal of Finance. Vol. 42, hal. 823837.

Bouzoita, R \& Young A. J. (1998).”A Probit Analysis of Best Ratings.”The Journal of Insurance Issues.

Brigham, E.F., dan J. Houston. 2001. Manajemen Keuangan. Penerjemah Hermawan Wibowo. Edisi Kedelapan. Edisi Indonesia. Buku II. Jakarta: Erlangga

Bringham, E. F., dan Louis C. Gapenski., 1996, Intermediate Financial Management, Fifth Edition, New York: The Dryden Press.

Burton et al. 1998. "The Determinant of Credit Ratings in the UK Insurance Industry." Download www.google.com. Diakses tanggal 4 Oktober 2015.

Christiawan, dan Tarigan Josua. 2007. Kepemilikan Manajerial: Kebijakan Utang, Kinerja, dan Nilai Perusahaan. Jurnal Akuntansi dan Keuangan, Vol. 9, No. 1 Mei 2007. 
Damayanti, Isrina. 2006. Analisis Pengaruh Free Cash Flow dan Struktur Kepemilikan Saham pada Kebijakan Utang Pada Perusahaan Manufaktur Indonesia. Skripsi. Fakultas Ekonomi Universitas Islam Indonesia.

Devi dan Erawati. 2014. Pengaruh Kepemilikan Manajrial, Leverage dan Ukuran Perusahaan pada Kebijakan dividen Perusahaan Manufaktur. E-Jurnal Akuntansi Universitas Udayana 9.3 (2014) : 709 - 716

Faisal, M. 2004. Analisis Pengaruh Free Cash Flow, Set Kesempatan Investasi, Kepemilikan Manajerial, dan Ukuran Perusahaan Pada Kebijakan Utang, Tesis. Universitas Diponegoro.

Farah Margaretha dan Aditya Rizky Ramadhan. 2010. Faktor-Faktor yang Mempengaruhi Struktur Modal pa Industri Manufaktur di Bursa Efek Indonesia. Jurnal Bisnis dan Akuntansi, Edisi 2, Vol. 12

Friend, I. and L. Lang. 1988. “An Empirical Test of The Impact of Managerial SelfInterest on Corporate Capital Structure.” Journal of Finance, 43: h:271-281.

Gaver, Jennifer J, dan Kenneth M.Gaver.1993."Additional Evidence on the Association between the Investment Opportunity Set and Corporate Financing, Dividen, and Compensation Policies." Journal Of Accounting \& Economics, 16: h:125-160.

Ghozali, Imam. 2009. Aplikasi Analisis Multivariate dengan Program SPSS. Semarang: BP Undip.

Harjanti, Tri, Theresia dan Eduardus, Tandelilin. 2007. Pengaruh Firm Size, Tangible Assets, Growth, Opportunity, Profitability, dan Business Risk pada Struktur Modal

Hardiningsih, Pancawati dan Rachmawati. 2012. Determinan Kebijakan Utang dalam Agency Theory dan Pecking Order Theory. Dinamika Akuntansi, Keuangan dan Perbankan. Jurnal Akuntansi 1(1): h:11 - 24.

Heru Setiawan. 2013. Pengaruh Ukuran Perusahaan, Reputasi Auditor, Opini Auditor, Profitabilitas, dan Solvabilitas Terhadap Audit Delay. Fakultas Ekonomi dan Bisnis Universitas Islam Negeri Syaif Hidayatullah Jakarta.

Horne, James C. Van dan John M. Wachowicz, Jr. 1998. Prinsip-prinsip Manajeman Keuangan. Jakarta: Salemba Empat.

Indahningrum dan Handayani. 2009. Pengaruh Kepemilikan Manajerial, Kepemilikan Institusional, Deviden, Pertumbuhan Perusahaan, Free Cash 
Flow, dan Profitabilitas pada Kebijakan Utang Perusahaan, Jurnal Bisnis dan Akuntansi, 3 Desember 2009, 11: h:189-207. Jakarta:Erlangga.

Ismiyanti, Fitri dan Mamduh, M, Hanafi. 2004. Stuktur Kepemilikan, Risiko dan Kebijakan Keuangan: Analisis Persamaan Simultan. Jurnal Ekonomi dan Bisnis Indonesia, Vol. 19, Hal 176-196.

Jensen, M. and W. H Meckling. 1976. "Theory of The Firm: Managerial Behavior, Agency Cost and Ownership Structure”, Journal of Financial Economics, 3-4, pp: 305-360.

Joher, Huson, Moch.Ali and Naxrul. 2006. The Impact Of Ownership Structure On Corporate Debt Policy: Two Stage Least Square Simultaneous Model Approach For Post Crisis Period: Evidence From Kuala Lumpur Stock Exchange. International Business \& Economics Research Journal. 5(5). Keempat. Yogyakarta: BPFE.

Kallapur, Sanjay and Mark A. Trombley. 1999. The Association Between Investment Opportunity Set Proxies and Realized Growth. Journal of Business Finance and Accounting, h:505-519.

Kurniati, Wahyuning. 2007. Pengaruh Struktur Kepemilikan Pada Kebijakan Utang Perusahaan. Tesis. Universitas Diponegoro.

Lestari, Holydia. 2004. Pengaruh Kebijakan Utang, Kebijakan Dividen, Risiko, danProfitabilitas Perusahaan Pada InvestmentOpportunity Set. Simposium Nasional Akuntansi (SNA) VII.

Listyani, Theresia Tyas., 2003, Kepemilikan Manajerial, Kebijakan Utang, dan Pengaru-hnya Terhadap Kepemilikan Saham Institusional (Studi pada Perusahaan Manu-faktur di Bursa Efek Jakarta), Jurnal Maksi, Vol 3, Agustus, Hlm. 98-114.

Mamduh. 2004. Manajemen Keuangan Edisi 1. Bpfe : Yogyakarta

Mas'ud, Masdar. 2008. Analisis Faktor-faktor yang Mempengaruhi Struktur-struktur Modal dan Hubungannya Terhadap Nilai Perusahaan. Jurnal MAnajemen dan Bisnis; Vol 7. No. 1, pp. 82-99.

Masdupi, Erni. 2005. Analisis Dampak Struktur Kepemilikan Pada Kebijakan Utang Dalam Mengontrol Konflik Keagenan Jurnal Ekonomi dan Bisnis Indonesia, Vol. 20, No. 1, Hlm. 57-69 
ISSN: 2302-8556

E-Jurnal Akuntansi Universitas Udayana

Vol.22.2. Februari (2018): 856-883

Megginson, W.L. (1977). Corporate Finace Theory. Reading, MA : Addison- Wesley Educational Publishers, Inc.

Moh'd, M.A., LG. Perry, J.N. Rombey, The Impact of Ownership Structure on Corporate Debt Policy : A Time Series Cross Sectional Analysis, Financial Review 30, 1998, Hal 85-99.

Munawir. 2004. Analisa Laporan Keuangan. Penerbit Liberty: Yogyakarta.

Myers., Stewart C.1983. The Capital Structure Puzzle., The Journal of Finance, Vol. 39, No. 3, Papers and Proceedings, Forty-Second Annual Meeting, American Finance Association, San Francisco, CA, December 28-30,. (Jul., 1984), pp. 575-592.

Nasser, Etty M., dan Fiel Yandi Firlano. 2006. Pengaruh Kepemilikan Institusional, Ukuran Perusahaan, Profitabilitas dan Utang Sebagai Variabel Intervening Terhadap Nilai Perusahaan. Jurnal Ekonomi STEI, Mei-Agustus, Hlm.105112.

Niswonger-Fess-Warren alih bahasa Supranoto, 1990, Prinsip-prinsip Akuntansi, Edisi ke-14. Jakarta: Erlangga

Nugroho, Ivan. 2011. Analisis Kepemilikan Institusional, Profitabilitas, dan Free Cash Flow pada Kebijakan Utang pada Perusahaan Manufaktur yang terdaftar di Bursa Efek Indonesia tahun 2006-2009. Skripsi. Fakultas Ekonomi Sebelas Maret.

Nuringsing, Kartika, 2002. Menciptakan Keunggulan Kompetitif Melalui Penilaian Kinerja $360^{\circ}$ Feedback ; Strategi dan Tantangan bagi Perusahaan, Manajemen Usahawan Indonesia, No.05/TH.XXXI

Pawestri, Pramudita. 2010. Pengaruh Free Cash Flow dan Managerial Ownership Pada Kebijakan Utang; Perspektif Pada Agency Theory. Skripsi. Sekolah Tinggi Ilmu Perbanas:Surabaya.

Riyanto, Bambang. 2001. Dasar-Dasar Pembelanjaan Perusahaan. Edisi Semarang: BP Undip.

Setiana, Esa dan Reffina Sibagariang. 2013. Pengaruh Free Cash Flow dan Kepemilikan Manajerial Pada Kebijakan Utang pada Perusahaan Manufaktur yang Terdaftar di Bursa Efek Indonesia. Jurnal Telaah Akuntansi. Juni 2013, 15 (1): h16 - 33.

Smith Jr.Clifford W.,dan Ross L.Watts. 1992. “The Investment Opportunity Set and 
Corporate Financing, Dividend,and Compensation Policies." Journal of Fianancial Economics, 2: h:263-292.

Suartawan, Yasa. 2016. Pengaruh Investment Opportunity Set dan Free Cash Flow pada Kebijakan Dividen serta Implikasinya pada Nilai Perusahaan Manufaktur di Bursa Efek Indonesia. Jurnal Akuntansi. Universitas Udayana: Bali.

Sugiyono. 2013. Statistika Untuk Penelitian. Bandung: Alfabeta

Sunder Shyam L. dan Myers S. C. (1999) “Testing Static Trade Off Against Pecking Order Models of Capital Structure." Journal of Financial Economics 51, pp:219-244.

Sutrisno, 2001, Manajemen Keuangan, Ekonesia: Yogyakarta.

Tarjo dan Jogiyanto. 2003. Analisa Free Cash Flow dan Kepemilikan Manajerial pada Kebijakan Utang pada Perusahaan Publik di Indonesia, Simposium Nasional Akuntansi VI Ikatan Akuntan Indonesia, h:278-290.

Utama, Suyana Made. 2009. Buku Ajar Aplikasi Analisis Kuantitatif Edisi Ketiga. Denpasar : Fakultas Ekonomi Universitas Udayana.

Wahidahwati. 2002. Pengaruh Kepemilikan Manajerial dan Kepemilikan Institutional pada Kebijakan Utang Perusahaan : Sebuah Perspektif Teori Agensi. Simposium Nasional Akuntansi IV Ikatan Akuntan Indonesia

Yeniatie dan Destriana, N. 2010. Faktor-Faktor Yang Mempengaruhi Kebijakan Utang pada Perusahaan Non Keuangan Yang Terdaftar di Bursa Efek Indonesia, Jurnal Bisnis dan Akuntansi. April 2010, 12(1): h:1-16.

Yulianto, Hidayat (2010). Pengaruh Kepemilikan Institusional, Free Cash Flow dan Kebijakan Dividen Pada Kebijakan Utang Perusahaan. Skripsi. Fakultas Ekonomi Universitas Sebelas Maret Surakarta.

Zulhawati., 2004, Analisis Dampak Kepemilikan Saham oleh Insider pada Kebijakan Utang dalam Mengontrol Konflik Keagenan, KOMPAK, No.11, Mei-Agustus, Hlm. 240-249. 